\title{
Variation of soil microbial population in different soil horizons
}

\begin{abstract}
Large diversity of micro flora and fauna are found in soil horizons. Microbial population in soil are determined by various factor such as soil depth, organic matter, porosity, oxygen and carbon dioxide concentration, soil PH, etc. Factors that influence microorganism role in nutrient building and cycling in soil and organic matter decomposition are of unique interest. Microorganisms decompose organic matter, detoxifying the toxic substance, fixing the nitrogen, transformation of nitrogen, phosphorous, potassium and other secondary \& micro nutrients are the major biochemical activities performed by microbes in soil. Low population of microorganism is found in the compact soil, soil with low organic matter percentage and on deeper strata of soil. So, this paper was reviewed to explore major factors that influence soil microbial population and its role in soil productivity. This was already established fact but main aim of this paper is to collect related information and conclude the future research prospects to strengthen the microorganism role in soil productivity and factor that influence growth of microorganism.
\end{abstract}

Keywords: soil fertility, microbial population, nutrient transformation, soil depth, soil organic matter
Volume 2 Issue 2 - 2015

\author{
Archana Bhattarai,' Bishwoyog Bhattarai,' \\ Sunil Pandey ${ }^{2}$ \\ 'Institute of Agriculture and Animal Sciences, Tribhuvan \\ University, Nepal \\ ${ }^{2}$ Nobel College Department of Medical Microbiology, Pokhara \\ University, Nepal
}

Correspondence: Bishwoyog Bhattarai, Institute of Agriculture and Animal Sciences, Tribhuvan University, Bhairahawa, Lumbini zone, Nepal,Tel +977984I021196, Email:bishwoyog12@gmail.com

Received: February 01, 2015 | Published: April 29, 2015

\section{Introduction}

Soil productivity is considered as an important factor for success of agricultural production rather than soil fertility. ${ }^{1,2}$ Status of nutrient present in the soil and its ability to supply the nutrient determines the fertility status of soil whereas ability of soil to produce higher yield is soil productivity. ${ }^{3,4}$ Crops are generally suited for particular textural class of soil so all fertile soils are not productive. Soil productivity depends upon several factors among which microbes' role is prominent.

Soil is a vibrant habitat for huge diversity of life-forms. It shelters many animals from invertebrates such as worms and insects to mammals like rabbits, rodents and badgers. It is also habitat of microorganisms. All these forms of life interrelate with each other and with the soil to create continually changing conditions. This allows changes in soil fertility and the soil productivity.

Microorganisms are very diverse and include all the bacteria, archaea and almost all the protozoa. They also include some fungi, algae, and certain animals such as rotifers. Microorganisms live in every part of the biosphere, including soil, hot springs, "7 miles deep" in the ocean, "40 miles high" in the atmosphere and inside rocks far inside within the Earth's crust. The mass of prokaryote, bacteria and archaea may be as much as 0.8 trillion tons of carbon. ${ }^{5}$ Recent studies indicate that airborne microorganisms play role in precipitation and weather. ${ }^{6}$ Microorganisms are also exploited in biotechnology, both in traditional food and beverage preparation, and in modern technologies based on genetic engineering.?

\section{Organic matter and microorganism population}

Soil contains many micro and macro flora and fauna as long as there is a carbon source for energy. A large number of bacteria in the soil exists, but because of their small size, they have a smaller biomass. Actinomycetes are 10 times smaller in number but are larger in size so they are similar in biomass to bacteria in soil. ${ }^{8,9}$ Although actinomycetes are heterogeneous group of gram-positive, generally anaerobic bacteria famed for a filamentous and branching ontogeny pattern that results, in most forms, in an extended colony, or mycelium, ${ }^{10}$ due to of this character they often consider separately in the group. Fungal population numbers are smaller but they dominate the soil biomass. ${ }^{11}$ Bacteria, actinomycetes and protozoa can tolerate more soil disturbance than fungal populations so they dominate in tilled soils while fungal and nematode populations tend to dominate in untilled. ${ }^{12,13}$ Soils contain about 8 to 15 tons of bacteria, fungi, protozoa, nematodes, earthworms, and arthropods. ${ }^{1}$ According to the study conducted by Johansson, ${ }^{14}$ agricultural field containing $4 \%$ organic matter has the following count of soil organisms (Table 1 ).

Table I Estimated content of organism in soil

\begin{tabular}{|c|c|c|c|}
\hline $\begin{array}{l}\text { Animal } \\
(2 \%)\end{array}$ & $\begin{array}{l}\text { Biomass No. } \\
\text { (kg/ha) }\end{array}$ & Plant (98\%) & $\begin{array}{l}\text { Biomass No. } \\
\text { (kg/ha) }\end{array}$ \\
\hline $\begin{array}{l}\text { Micro: } \\
\text { Protozoa }\end{array}$ & $100\left(10^{4}-10^{5} / \mathrm{gm}.\right)$ & $\begin{array}{l}\text { Micro: } \\
\text { Bacterial }\end{array}$ & $\begin{array}{l}5000\left(10^{8}-10^{9} /\right. \\
\text { gm.) }\end{array}$ \\
\hline Nematode & $\begin{array}{l}2-100\left(10-10^{2} /\right. \\
\text { gm.) }\end{array}$ & Actinomycetes & $\begin{array}{l}1500\left(10^{7}-10^{8} /\right. \\
\text { gm.) }\end{array}$ \\
\hline $\begin{array}{l}\text { Macro: } \\
\text { Earthworm }\end{array}$ & $50\left(3.3 * 10^{5} / \mathrm{HFS}\right)$ & Fungi & $\begin{array}{l}5000\left(10^{5}-10^{6} /\right. \\
\text { gm.) }\end{array}$ \\
\hline Myriapodas & $40\left(5.5 * 10^{6} / \mathrm{HFS}\right)$ & Algae & $10\left(10^{4}-10^{5} / \mathrm{gm}.\right)$ \\
\hline Insects & $10-100$ (50/HFS) & $\begin{array}{l}\text { Macro: Plant } \\
\text { roots }\end{array}$ & 4000 \\
\hline Rodents & 5 & & \\
\hline
\end{tabular}

Source: Johansson 1979

Similarly the study of Torsvik et al., ${ }^{11}$ showed the similar count of the micro flora and fauna on the surface soil horizon. The rhizosphere, area around the effective root zone, can comprise up to $10^{11}$ Microorganism cells per gram of root and above 30,000 prokaryotic 
species in general. ${ }^{15}$ This indicates organic compound have a positive correlation with the microorganism population. Soil rich in organic matter has higher count of micro flora and fauna than soil with low organic matter. Forest soil is rich in micro flora and fauna. ${ }^{16}$ And soil containing higher number of micro flora and fauna are considered as a living soil.

\section{Soil depth and microorganism population}

Soil profiles are many meter deep and soil varies from place to place. The microorganism population also varies with the depth. The study conducted by the James J. Hoorman and Rafiq Islam- Ohio State University showed following result on relative number and biomass of microorganism species at $0-15 \mathrm{~cm}$ depth of soil (Table 2). Similarly studies conducted by Fierer et al., ${ }^{17}$ have showed the decreasing microorganism population with increasing soil depth (Table 3 ).

Table 2 Microorganism species at $0-15 \mathrm{~cm}$ depth of soil

\begin{tabular}{lll}
\hline Microorganisms & Number/g of Soil & Biomass $\left(\mathrm{g} / \mathrm{m}^{2}\right)$ \\
\hline Bacteria & $10^{8}-10^{9}$ & $40-500$ \\
Actinomycetes & $10^{7}-10^{8}$ & $40-500$ \\
Fungi & $10^{5}-10^{6}$ & $100-1500$ \\
Algae & $10^{4}-10^{5}$ & Jan-50 \\
Protozoa & $10^{3}-10^{4}$ & Varies \\
Nematodes & $10^{2}-10^{3}$ & Varies
\end{tabular}

Source: Hoorman and Islam- Ohio State University

Table3 Decreasing microorganism population with increasing soil depth

\begin{tabular}{lll}
\hline Profile & Soil Depth $(\mathbf{c m})$ & Microorganism Biomass $\left(\mathbf{g} / \mathbf{m}^{2}\right)$ \\
\hline & $0-5$ & $9.8(1.6)$ \\
& $5-15$ & $4.0(0.16)$ \\
Terrace & $15-25$ & $2.0(0.12)$ \\
& 50 & $0.63(0.044)$ \\
& 100 & $0.18(0.030)$ \\
& 200 & $0.081(0.0053)$ \\
& $0-5$ & $16(0.040)$ \\
Valley & $5-15$ & $5.1(0.41)$ \\
& $15-25$ & $2.5(0.16)$ \\
& 50 & $0.84(0.077)$ \\
& 100 & $0.41(0.093)$ \\
& 200 & $0.11(0.043)$ \\
\hline
\end{tabular}

\section{Soil aeration and microorganism population}

Microorganism population in soil is limited by soil porosity, more the pore space higher is the count of microbes. ${ }^{18-20}$ Well tilled soil is well aerated and favors microorganism growth. The microbial population is found to be more in $\mathrm{O}_{2}$ rich soil compared to $\mathrm{CO}_{2} \cdot{ }^{21} \mathrm{~A}$ major contributor to poor aeration is soil compaction. ${ }^{2}$ Soil compaction can create problems by alterations in the physical properties of the soil including: decreases in total pore space, decreasing soil oxygen content, reductions in water infiltration and percolation rates, increases in soil strength and density, and increased water retention. ${ }^{1,22}$ Soil compaction increase with increase in depth..$^{23,24}$

\section{Microbes in soil fertility}

The agriculturally beneficial microorganisms are plant growth promoting $\mathrm{N}$-fixing cyanobacteria, rhizobacteria, mycorrhiza, plant disease suppressive beneficial bacteria, stress tolerance entophytes and bio-degrading microbes. Count of Azotobacter, Azospirillum, Rhizobium, cyanobacteria, phosphorus and potassium solubilizing microorganisms and mycorrhizae where high under no tillage or minimum tillage soil. ${ }^{25}$ Bacterial are the important soil microorganism responsible for many enzymatic transformation like nitrification, ammonification etc. Azosprillum is micro aerobic that fixes the nitrogen in association with roots of grasses. Inoculation of Azosprillum to the grass crops have positive hormonal effect on roots and plant growth. ${ }^{26,27}$ Rhizobium alone in symbiotic association with legume fixes about $50-200 \mathrm{~kg}$ of $\mathrm{N}_{2}$ per hectare. The following table shows the amount of nitrogen fixed by the different microorganism with symbiotic association with different species of plant (Table 4).

Nonsymbiotic association of Azobacter, Clostridium fixes about $5-20 \mathrm{~kg} \mathrm{~N} / \mathrm{ha} / \mathrm{yr}$ 's and various species of blue green algae fixes about $10-50 \mathrm{~kg} \mathrm{~N} / \mathrm{ha} / \mathrm{yr}$ 's. ${ }^{1,26}$ Two fungi Aspergillus fumigatus and A. niger isolated from decaying cassava peels were found to convert cassava wastes to phosphate bio-fertilizers. ${ }^{27}$

Nitrifying bacteria of the genus Nitrosamines produce nitrite ions from the oxidation of ammonia. Bacteria of the genus Nitrobacter and a few other genera can oxidize nitrites to nitrates. Nitrogen fixers such as Clostridium pasteurianum are obligate anaerobes, they convert atmospheric nitrogen in ammonia and fix in soil. Study conducted by Boyle et al., ${ }^{28}$ showed that fungal: bacterial ratios were significantly low at the high-productivity site compared to the low-productivity site. The presence of red alder (Alnus rubra) increased gross and net nitrification and processes were mediated by prokaryotes. They also suggest that the main sink for $\mathrm{NH}^{4+}$ in soils may be autotrophic nitrifies. ${ }^{28}$ Acid products of bacterial fermentations convert insoluble phosphates into soluble phosphates which are now utilized by plant for growth. Vascular carbuncular mycorrhiza in association with plant roots converts insoluble phosphate into soluble one. Bacteria such as Thiobacillus ferrooxidans and iron bacteria of the genus Gallionella are capable of oxidizing ferrous $\left(\mathrm{Fe}^{2+}\right)$ iron into ferric $\left(\mathrm{Fe}^{3+}\right)$ iron. ${ }^{29}$

Soil flora and fauna plays a great role in improving the soil texture, nutrient and crop productivity. Bacteria on decomposing plant tissue secrets polysaccharides and other organic glue. Sticky sugar-protein called glomalin secreted by mycorrhizae possess cementing properties which helps to hold the soil particles together. Also decomposition of organic component by the bacteria increases the soil porosity which increases the infiltration capacity, thus protects the soil from the erosion..$^{14,22}$

Table 4 Amount of nitrogen fixed by the different microorganism

\begin{tabular}{lll}
\hline Crop or Plant & Associated Organism & Typical Level of $\mathbf{N}_{\mathbf{2}}$ Fixation (kgN/ha/yrs.) \\
\hline Ipil-Ipil (Leucaena leucocephala) & Rhizobium & $100-500$ \\
Alfa-Alfa (Medicago sativa) & Rhizobium & $150-250$ \\
\hline
\end{tabular}




\begin{tabular}{lll} 
Table continued & & \\
\hline Crop or Plant & Associated Organism & Typical Level of $\mathbf{N}_{\mathbf{2}}$ Fixation (kgN/ha/yrs.) \\
\hline Clover (Trifolium pratense) & Rhizobium & $100-150$ \\
Cow Pea (Vigna unguiculata) & Bradyrhizobium & $50-100$ \\
Pigeon Pea (Cajunus Cajan) & Bradyrhizobium & $150-280$ \\
Alder (Alnus) & Frankia & $50-150$ \\
Species of Gunnera & Nostoc & $10-20$ \\
Azolla & Anabaena & $150-300$ \\
Digtriad accumbens & Azospirillum & $5-30$ \\
\hline
\end{tabular}

Source: Nature and Properties of Soil, 2012

\section{Conclusion}

There are lots of papers found on soil organic matter, soil aeration, change in soil fertility status with depth however there still lacks the overall role of each component in soil fertility. Soil organic matter, depth and aeration pays a great role in the determining the soil micro flora and fauna. Organic matter and aeration have positive correlation in building the microorganism population where depth has the negative correlation. Also with increasing soil depth soil aeration and organic matter decreases, thus decrease the microorganism population. This indicates that surface soil is rich in microorganism population since the entire environment such as organic compound, aeration, temperature, etc. favors the growth of microorganism and vice versa in the deeper strata of soil. This indicates the general gradient of soil fertility in respect to the soil depth.

At present context, in the globe the soil is being compacted with the heavy agricultural equipment which have created soil horizon devoid of air space. The soil density has increased resulting in the decrease in the porosity of the soil and limiting the microorganism growth. Similar is the case with the organic matter. Present agricultural practice uses a chemical fertilizer limiting use of organic matter. As a consequence the microorganisms are deprived of food and their growth has been checked. This has created imbalance in the soil ecosystem which have resulted in the poor structure and less fertile soil.

Therefore to create healthy and fertile soil we must provide the environment that favors the growth of microorganism. For this addition of organic matter, loosening the soil mass, providing the optimum moisture in soil, reducing the heavy agricultural equipment, replacing chemicals with alternative source of manure, could be few steps towards ecofriendly soil with high microbial population.

\section{Acknowledgments}

None.

\section{Conflicts of interest}

Authors declare that there is no conflict of interest.

\section{References}

1. Brady NC, Weil RC. The Nature and Properties of Soils. (14 ${ }^{\text {th }}$ edn.), Dorling Kindersley India Pvt. Ltd: Noida, India; 2012.

2. Day SD, Bassuk NL. A review of the effects of soil compaction and amelioration treatments on landscape trees. Journal of Arboriculture. 1994;20(1):9-17.

3. Stine MA, Weil RR. The relationship between soil quality and crop productivity across three tillage systems in south central Honduras. American Journal of Alternative Agriculture. 2002;17(1):2-8.
4. Onduru DD, Jager AD, Wouters B, et al. Improving Soil Fertility and Farm Productivity under Intensive Crop-Dairy Smallholdings: Experiences from Farmer Field Schools in the Highlands of Kiambu District, Central Kenya. Middle-East Journal of Scientific Research. 2006;1(1):31-49.

5. Eilers $\mathrm{KG}$, Debenport $\mathrm{S}$, Anderson $\mathrm{S}$, et al. Digging deeper to find unique microbial communities: The strong effect of depth on the structure of bacterial and archaeal communities in soil. Soil Biology and Biochemistry. 2012;50:58-65.

6. Hardy J. The rain making bacteria. ASCP: California, USA; 1990.

7. Bourgaize D, Jewell TR, Buiser RG. Biotechnology: Demystifying the concept. ( $2^{\text {nd }}$ edn.), Persion Education: Delhi, India; 2004.

8. Hoorman JJ, Islam R. Understanding soil microbes and nutrient recycling. Agricultural and Natural Resource. 2010;16(10).

9. Schmidt SK, Gier MJ. Dynamics of Microbial Populations in Soil: Indigenous Microorganisms Degrading 2,4-Dinitrophenol. Microb Ecol. 1989;18(3):285-296.

10. Rao NS. Soil Microorganisms and Plant growth. ( $4^{\text {th }}$ edn.), Oxford and IBH Publishng Co. Pvt. Ltd: New Delhi, India; 2005. 407 p.

11. Cocks LRM, Torsvik TH. Earth Geography from 500 to 400 million years ago: Faunal and palaeomagnetic review. J Geol Soc Lond. 2002;159:631-644.

12. Janusauskaite D, Kadziene G, Auskalniene O. The effect of tillage system on soil microbiota in relation to soil structure. Pol J Environ Stud. 2013;22(5):1387-1391.

13. Silva AP, Babujia LC, Matsumoto LS, et al. Bacterial Diversity Under Different Tillage and Crop Rotation Systems in an Oxisol of Southern Brazil. The Open Agriculture Journal. 2013;7(Supp 11-M6):40-47.

14. Watson GW, Kelsey P. The impact of soil compaction on soil aeration and fine root density of Quercus palustris. Urban Forestry \& Urban Greening. 2006;4(2):69-74.

15. Egamberdieva D, Kamilova F, Validov S, et al. High incidence of plant growth-stimulating bacteria associated with the rhizosphere of wheat grown on salinated soil in Uzbekistan. Environ Microbiol. 2008;10(1):1-9.

16. Mandal SN. Brief Introduction to Soil. Department of Agriculture: Lalitpur, Nepal; 2013.

17. Fierer N, Schimel JP, Holden PA. Variation in microbial community composition through two soil depth profile. Soil Biology and Biochemistry. 2003;35(1):167-176.

18. Collins H. Impacts of Fumigation and Crop Rotation on soil Microbial Populations. USDA-ARS Irrigated Research Center: USA; 2010.

19. Grubinger V. Soil Microbiology: A Primer. University of vermont: Burlington, USA; 2004. 
20. Magdoff F, ES VH. Building Soils for Better Crops: Sutainable Soil Management. (3rd edn.), Sustainable Agriculture Research and Education: USA; 2010. 294 p.

21. McNabb DH, Startsev AD. Effects of compaction on aeration and morphology of boreal forest soils in Alberta, Canada. Canadian Journal of Soil Science. 2009;89(1):45-56.

22. Stier JC. Lawn Aeration and Topdressing. University of WisconsinExtension: USA; 2000.

23. Gilman EF, Leone IA, Flower FB. Effect of soil compaction and oxygen content on vertical and horizontal root distribution. $J$ Environ Hort. 1987;5(1):33-36.

24. Swer H, Dkhar MS, Kayang H. Fungal population and diversity in orginically amended agricultural soils of meghalaya, India. Journal of Organic Systems. 2011;6(2):3-12.
25. Bhardwaj D, Ansari MW, Sahoo RK, et al. Biofertilizers function as key player in sustainable agriculture by improving soil fertility, plant tolerance and crop productivity. Microb Cell Fact. 2014;13:66.

26. Dastager SG, Deepa CK, Pandey A. Isolation and characterization of novel plant growth promoting Micrococcus sp NII-0909 and its interaction with cowpea. Plant Physiol Biochem. 2010;48(12):987-992.

27. Ogbo FC. Conversion of cassava wastes for biofertilizer production using phosphate solubilizing fungi. Bioresour Technol. 2010;101(11):4120-4124.

28. Boyle SA, Yarwood RR, Bottomley PJ, et al. Bacterial and Fungal Contributions to Soil Nitrogen Cycling under Douhlas Fir and Red Alder at two sites on Oregon. Soil Biology and Biochemistry. 2008;40(2):441-451.

29. Hertage J, Evans EGV, Killington RA. Microbiology in Action. Cambridge University Press: London; 1999. 